\title{
Smoking among Saudi university students: consumption patterns and risk factors
}

\author{
A. Mandil, ${ }^{1}$ A. BinSaeed, ${ }^{1}$ R. Dabbagh, ${ }^{1}$ S.A. Shaikh, ${ }^{1}$ M. AlSaadi ${ }^{2}$ and M. Khan ${ }^{3}$
}

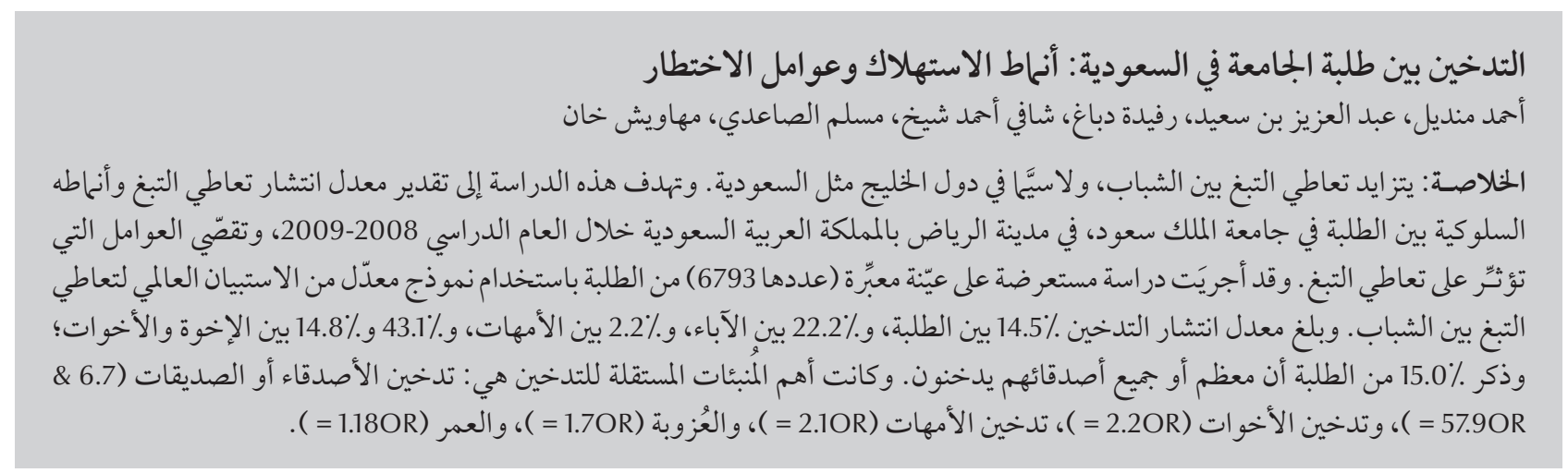

ABSTRACT Tobacco use is increasing among young people, especially in Gulf nations such as Saudi Arabia. The objectives of this study were to estimate the prevalence and behavioural patterns of tobacco use among undergraduate students at King Saud University, Riyadh, Saudi Arabia during the academic year 2008/09 and investigate factors that influenced their tobacco use. A cross-sectional study was done of a representative sample ( $n=6793$ ) of the undergraduate student population using a modified version of the global youth tobacco survey questionnaire. The prevalence of smoking was $14.5 \%$ among students, $22.2 \%$ and $2.2 \%$ among fathers and mothers and $43.1 \%$ and $14.8 \%$ for male and female siblings; $15.0 \%$ reported all or most of their friends smoked. The most important independent predictors of smoking were: friends' smoking (some: $O R=6.7$ and all: $O R=54.9$ ), sister's smoking $(O R=2.2)$, mother's smoking $(O R=2.1)$, single status $(O R=1.7)$ and age $(O R=1.18)$.

\section{Tabagisme chez les étudiants saoudiens à l'université : modes de consommation et facteurs de risque}

RÉSUMÉ La consommation de tabac est en augmentation chez les jeunes, en particulier dans les pays du Golfe tels que l'Arabie saoudite. La présente étude visait à estimer la prévalence de la consommation de tabac chez les étudiants de premier cycle à I'Université King Saud à Riyadh (Arabie saoudite) pendant l'année universitaire 2008-2009 et à évaluer leur comportement en la matière, mais aussi à rechercher les facteurs influençant cette consommation. Une étude transversale a été conduite sur un échantillon représentatif $(n=6793)$ de la population des étudiants de premier cycle aux moyens du questionnaire de l'enquête mondiale sur le tabagisme chez les jeunes dans une version modifiée. La prévalence du tabagisme était de 14,5\% chez les étudiants, de 22,2 \% chez les pères et de 2,2 \% chez les mères, de 43,1 \% chez les frères et de 14,8 \% chez les sœurs. Les étudiants interrogés ont été $15,0 \%$ à déclarer que tous leurs amis ou la plupart d'entre eux étaient fumeurs. Les facteurs prédictifs indépendants les plus importants pour la consommation de tabac étaient les suivants : le tabagisme des amis (O.R. = 6,7 [certains des amis] et O.R. = 54,9 [tous les amis]), d'une sœur (O.R. =2,2), de la mère (O.R. = 2,1), le fait d'être célibataire (O.R. =1,7) et l'âge (O.R. =1,18).

${ }^{7}$ Department of Family and Community Medicine; ${ }^{2}$ Department of Paediatrics; ${ }^{3}$ Department of Epidemiology and Public Health, College of Medicine, King Saud University, Riyadh, Saudi Arabia (Correspondence to A. Mandil: ahmed.mandil@yahoo.com).

Received: 19/06/10; accepted: 07/07/10 


\section{Introduction}

Tobacco use is increasing among young people. For the period 1999-2008, the World Health Organization (WHO)/ Centers for Disease Control global youth tobacco survey (GYTS) has shown that smoking starts as early as $13-15$ years. Estimates of current cigarette smoking at this age in Eastern Mediterranean Region (EMR) nations range from $2 \%$ among girls to $7 \%$ among boys, but for waterpipe smoking the rates are higher for both sexes, ranging from $9 \%$ among girls to $14 \%$ among boys. Moreover, susceptibility to initiate smoking was estimated to range between 14\% (girls) and 20\% (boys) in the same age group [1]. In 2007, the GYTS in Saudi Arabia estimated that $6.7 \%$ of $13-15$-year-old students currently smoked cigarettes and an estimated $11.9 \%$ currently smoked waterpipes [2]. Studies on tobacco use and its risk factors among secondary-school students in Gulf countries have been carried out in Bahrain [3], Saudi Arabia [4-7], Kuwait [8] and Yemen [9], and can be compared with high-school students in the Syrian Arab Republic [10] and Egypt [11]. In spite of the many studies carried out in the EMR on tobacco consumption among secondary/ high-school students, only some have focused on university students, such as studies performed in Saudi Arabia [12], Jordan [13], Egypt [14], Lebanon [15], Bahrain [16] and the United Arab Emirates (UAE) [17].

A compendium of tobacco consumption surveys in Saudi Arabia during the past decade (1999-2009) has shown that the prevalence estimates of tobacco use among young adults of university age range from $2.4 \%-37.0 \%$. Such studies have also demonstrated that smoking, particularly cigarettes and waterpipes, is a widespread problem, which is increasing in scale and over time [18]. Higher prevalence has been associated with age, being male, single and highly educated. Desire, idleness, peer pressure and enjoyment were examined as predictors for smoking among youngsters in Saudi Arabia [4-7].

Although many studies have been conducted in Saudi Arabia regarding tobacco consumption among secondary and university students (especially males), university-wide surveys are needed to highlight tobacco consumption patterns and different risk factors that may contribute to adoption of the habit among Saudi youngsters, comparing students of different sexes, majors and school years. Thus, the objectives of this study were to estimate the prevalence and behavioural patterns of tobacco use among undergraduate students at King Saud University, Riyadh, Saudi Arabia during the academic year 2008/09 and investigate different factors that contribute to tobacco use among the students.

\section{Methods}

\section{Sample}

A cross-sectional approach was used for data collection, which took place during the academic year 2008/09. A representative sample of the total King Saud University undergraduate student population of 69498 (males and females) was selected, based on an estimated prevalence of tobacco use in Saudi Arabia of 24\%-25\%, which is higher than the average mentioned above. The sample was stratified according to college, and then clusters of classes were taken from each stratum. The total target student population of 69498 was stratified according to college and sex. Different colleges were further stratified into 3 groups according to type of studies: health-related colleges (including: medicine, dentistry, nursing, pharmacy and applied medical sciences); non-health related colleges (including science, computer science, arts, education, language and translation, administrative sciences); and Islamic studies. The initial sample of 7550 male and female students comprised 2500 students from health-related colleges (to ensure good representation of this group in the sample) and 5250 students from non-health-related colleges.

The inclusion criteria for the study sample were: full-time student status, enrolment in one of the university's undergraduate programmes during the academic year 2008/09, studying at the Riyadh campus, age range $17-25$ years.

\section{Data collection}

The GYTS questionnaire [19] was used for data collection, modified to suit the King Saud University student population (rather than a school population), and 2 versions for males/females were used, with questions in Arabic language. The original Arabic GYTS version has been validated by WHO in different Arabic speaking countries, and a pilot study was carried out on 50 students to finetune the questions before actual data collection.

The self-administered questionnaire covered demographic data (age, sex, college, marital status, employment); tobacco use patterns (type of smoking, frequency, age of initiation, duration), as well as possible risk factors which could encourage students to start smoking. A smoker was defined as someone who was currently using $\geq 1$ tobacco products (cigarettes, waterpipe, etc.). Current smoking included daily, non-daily and occasional smoking (according to WHO, prevalence of current tobacco use among adults aged $>15$ years).

The questionnaires were distributed and collected by 40 medical students. The anonymity of participants was emphasized and confidentiality strictly maintained on all collected questionnaires. Permission of the dean of the college and the instructors of selected classes was obtained to collect data during classes. Approval of King Saud University research ethics committee as well as administrative sections in different college departments was obtained. 


\section{Data analysis}

Data were reviewed on a daily basis for completeness and accuracy, then managed and analysed using SPSS, version 17.0. Data management included coding, cleaning, entry, analysis and presentation in tables. Descriptive statistics [mean, standard deviation (SD) and proportion] were used to describe the study variables. The chi-squared test was used to test for associations and the chi-squared test for trend and Student $t$-test for independent samples were used for bivariate analyses. Crude odds ratios (OR), with 95\% confidence intervals, were calculated to measure the strength of association of each of the categorical variables with the nominal outcome variable (smoking status). The Breslow-Day test was used to test for the possible effect modification by some variables on the outcome variable. Stepwise multiple logistic regression was then used to arrive at the adjusted OR to identify the most important predictors for smoking among students in our sample. A $P$-value $<0.05$ was considered statistically significant.

\section{Results}

\section{Background data}

The response rate for distributed questionnaires was about 90\% (6793 from the target of 7550 students), but not all questions were attempted by all participants. The mean age of the participants was 21 (SD 1.9) years. As seen in Table $1,44.5 \%$ of students were males and $55.5 \%$ females. Most sampled students were single (90.0\%). As planned during sampling, about one-third of the students were from health-related colleges (33.2\%). More students participated from the first 4 years of study ( $87.5 \%$ ) than from the final 2 years (5th and 6th) (12.5\%), who were predominantly from health-related colleges. More mothers of students in our sample (12.8\%) were reported to "neither read nor write" than fathers (6.6\%). Also, more mothers

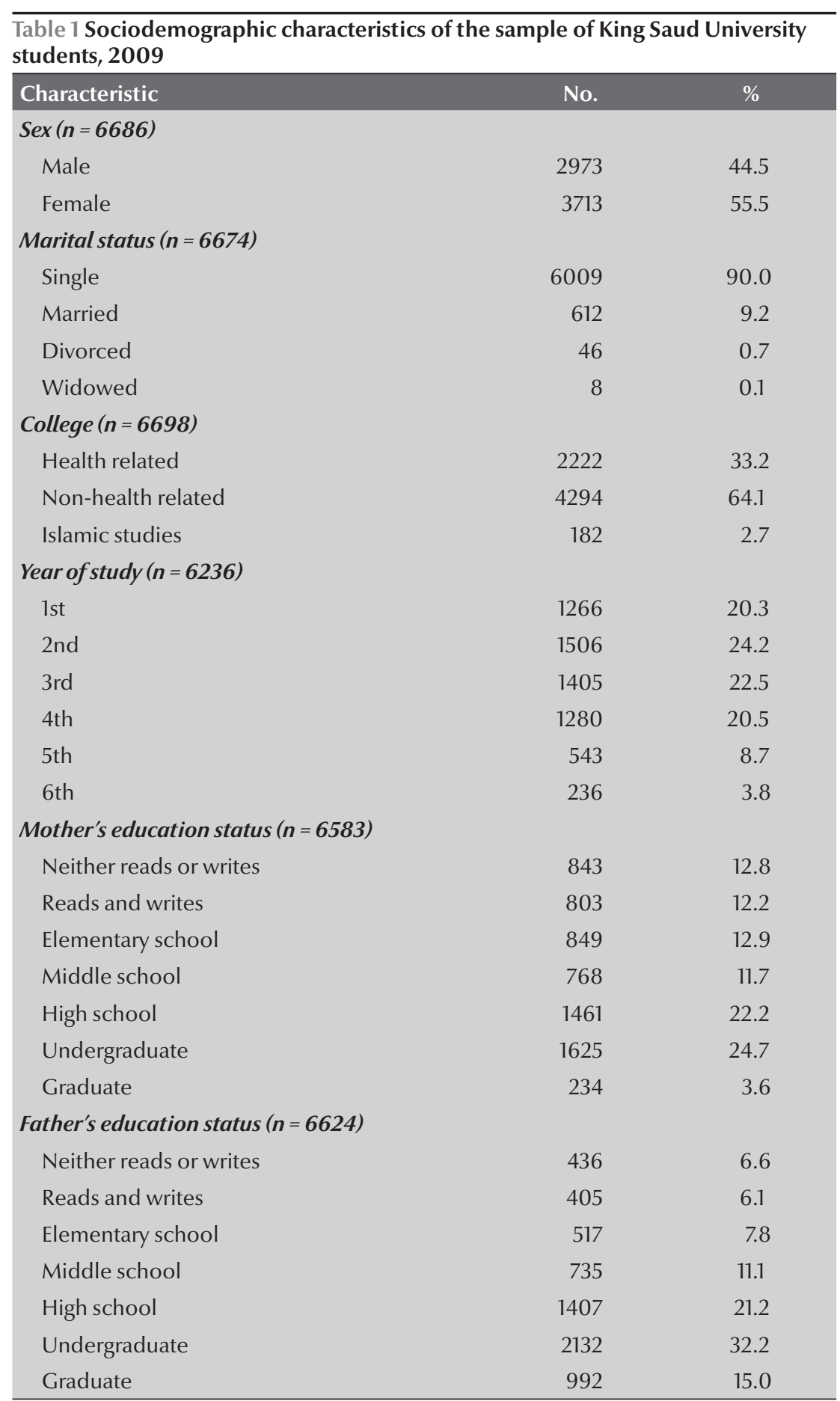

(59.0\%) than fathers (46.2\%) had received basic education, while more fathers (47.2\%) than mothers (28.3\%) had received university education (including graduate studies) (Table 1).

\section{Prevalence of smoking}

The overall prevalence of smoking among students in our sample was 14.5\% (Table 2); among fathers and mothers prevalence was $22.2 \%$ and $2.2 \%$ respectively and $15.0 \%$ reported that most or all of their friends smoked.

Table 3 shows the consumption pattern of smoking with respect to type of tobacco product. More male smokers reported consuming cigarettes (48.2\%) compared with waterpipe (36.4\%) and snuff (4.3\%); the distribution among female smokers was similar. On the 


\begin{tabular}{|c|c|c|c|}
\hline \multirow[t]{2}{*}{ Characteristic } & \multicolumn{2}{|c|}{ Smoking status } & \multirow[t]{2}{*}{$95 \% \mathrm{CI}$} \\
\hline & No. & $\%$ & \\
\hline Total $(n=6793)$ & 986 & 14.5 & $13.7-15.3$ \\
\hline Father $(n=6646)$ & 1475 & 22.2 & $21.2-23.2$ \\
\hline Mother $(n=6534)$ & 147 & 2.2 & $1.8-2.5$ \\
\hline Brother $(n=6793)$ & 2929 & 43.1 & $39.4-46.8$ \\
\hline Sister $(n=6793)$ & 1004 & 14.8 & 13.9-15.6 \\
\hline \multicolumn{4}{|l|}{ Friends $(n=6486)$} \\
\hline Some & 2081 & 32.1 & $28.5-35.7$ \\
\hline Most & 831 & 12.8 & $12.0-13.6$ \\
\hline All & 142 & 2.2 & $1.8-2.5$ \\
\hline
\end{tabular}

$C I=$ confidence interval.

other hand, an almost equal distribution of smoking type was reported from health-related college students for cigarettes (45.5\%) and waterpipe (45.2\%). This was very different from non-health related students (51.3\% and 31.2\% respectively). Greater cigarette than waterpipe consumption was observed across all years of study (Table 3).

\section{Bivariate analyses}

Table 4 shows the results of bivariate analyses when cross-tabulating smoking status (outcome variable) with independent potential risk factors: sex, marital status, type of studies, year of study, family member smoking status and peer (friend) smoking status. Sex was significantly associated with smoking status, as there were 778 (32.7\%) male smokers compared with only 181 $(5.9 \%)$ females $(\mathrm{OR}=7.8, P<0.001)$. Moreover, marital status (comparing single with married subjects) was significantly associated with smoking status $(\mathrm{OR}=1.8, \mathrm{P}<0.001)$. Students of Islamic studies were at lower risk of smoking than students studying in health-related $(\mathrm{OR}=2.1, P=0.018)$ and non-health related $(\mathrm{OR}=2.3, P$
$=0.004)$ departments. In addition, a highly statistically significant rising trend of smoking risk was observed from freshmen in their 1st year of study to final year students in the 6th year $(\mathrm{OR}=3.0, P<0.001)$.

Parent's (bothfather'sandmother's) education level was not significantly associated with the smoking status of study subjects. But father's $(\mathrm{OR}=1.8)$, mother's $(\mathrm{OR}=2.8)$ and sister's ( $\mathrm{OR}$ $=6.1$ ) smoking habits had a statistically significant association with the smoking habit of the sample $(P<0.001)$. Surprisingly, our data did not show a statistically significant association between the smoking status of study subjects and brother's smoking status ( $\mathrm{OR}=$ $0.9, P=0.29$ ). Also, a increasing trend of risk of smoking among students was observed according to friends' smoking status (peer pressure), which increased significantly from some friends (OR $=8.8)$ to most friends $(\mathrm{OR}=44.0)$ to all friends $(\mathrm{OR}=75.5)\left(\chi^{2}=1451.9\right.$, $P<0.001)($ Table 4$)$.

Thus, peer pressure was used as the most important predictor for smoking among students in our sample for further analysis for potential effect modification by variables (sex, paternal

\begin{tabular}{|c|c|c|c|c|c|c|c|c|c|}
\hline \multirow[t]{2}{*}{ Variable } & \multicolumn{2}{|c|}{ Cigarettes } & \multicolumn{2}{|c|}{ Waterpipe } & \multicolumn{2}{|c|}{ Snuff } & \multicolumn{2}{|c|}{ Other } & \multirow{2}{*}{$\begin{array}{c}\text { Total } \\
\text { No. }\end{array}$} \\
\hline & No. & $\%$ & No. & $\%$ & No. & $\%$ & No. & $\%$ & \\
\hline Total & 547 & 48.2 & 413 & 36.4 & 50 & 4.4 & 117 & 10.3 & 1136 \\
\hline \multicolumn{10}{|l|}{ Sex } \\
\hline Male & 475 & 51.1 & 344 & 37.0 & 40 & 4.3 & 61 & 6.6 & 929 \\
\hline Female & 72 & 34.8 & 69 & 33.3 & 10 & 4.8 & 56 & 27.1 & 207 \\
\hline \multicolumn{10}{|l|}{ College } \\
\hline Health-related & 172 & 45.5 & 171 & 45.2 & 8 & 2.1 & 27 & 7.1 & 378 \\
\hline Non-health-related & 383 & 51.3 & 233 & 31.2 & 41 & 5.5 & 90 & 12.0 & 747 \\
\hline Islamic studies & 9 & 52.9 & 7 & 41.2 & 0 & 0 & 1 & 5.9 & 17 \\
\hline \multicolumn{10}{|l|}{ Year of study } \\
\hline $1 s t$ & 80 & 47.6 & 50 & 29.8 & 8 & 4.8 & 30 & 17.9 & 168 \\
\hline 2nd & 97 & 47.1 & 70 & 34.0 & 13 & 6.3 & 26 & 12.6 & 206 \\
\hline $3 r d$ & 124 & 50.8 & 83 & 34.0 & 14 & 5.7 & 23 & 9.4 & 244 \\
\hline 4th & 95 & 43.6 & 93 & 42.7 & 6 & 2.8 & 24 & 11.0 & 218 \\
\hline 5th & 81 & 53.3 & 65 & 42.8 & 3 & 2.0 & 3 & 2.0 & 152 \\
\hline 6th & 32 & 45.1 & 31 & 43.7 & 1 & 1.4 & 7 & 9.9 & 71 \\
\hline
\end{tabular}




\begin{tabular}{|c|c|c|c|c|c|}
\hline \multirow[t]{2}{*}{ Variable } & \multicolumn{2}{|c|}{ Smoking status } & \multirow[t]{2}{*}{ OR } & \multirow[t]{2}{*}{$95 \% \mathrm{Cl}$} & \multirow[t]{2}{*}{$P$-value } \\
\hline & Smoker & $\begin{array}{c}\text { Non- } \\
\text { smoker }\end{array}$ & & & \\
\hline \multicolumn{6}{|l|}{ Sex } \\
\hline Male & 778 & 1603 & 7.8 & $6.5-9.2$ & $<0.001$ \\
\hline Female & 181 & 2891 & & & \\
\hline \multicolumn{6}{|l|}{ Marital status } \\
\hline Single & 897 & 3988 & 1.8 & $1.3-2.4$ & $<0.001$ \\
\hline Married & 57 & 454 & 1.0 & & - \\
\hline Divorced/widowed & 11 & 48 & 1.8 & $0.8-3.9$ & 0.14 \\
\hline \multicolumn{6}{|l|}{ College } \\
\hline Health-related & 309 & 1482 & 2.1 & $1.2-3.9$ & 0.018 \\
\hline Non-health-related & 652 & 2856 & 2.3 & $1.3-4.4$ & 0.004 \\
\hline Islamic studies & 13 & 134 & 1.0 & & - \\
\hline \multicolumn{6}{|l|}{ Year of study } \\
\hline 1st & 145 & 905 & 1.0 & & - \\
\hline 2nd & 178 & 1046 & 1.1 & $0.8-1.3$ & 0.66 \\
\hline $3 \mathrm{rd}$ & 204 & 945 & 1.3 & $1.1-1.7$ & 0.01 \\
\hline 4 th & 186 & 877 & 1.3 & $1.0-1.7$ & 0.02 \\
\hline 5 th & 128 & 308 & 2.6 & $2.0-3.4$ & $<0.001$ \\
\hline 6 th & 57 & 118 & 3.0 & $2.1-4.4$ & $<0.001$ \\
\hline \multicolumn{6}{|l|}{ Father's education status } \\
\hline Neither reads nor writes & 70 & 287 & 1.2 & $0.9-1.7$ & 0.27 \\
\hline Reads and writes & 63 & 262 & 1.2 & $0.8-1.7$ & 0.33 \\
\hline Elementary school & 79 & 321 & 1.2 & $0.9-1.7$ & 0.25 \\
\hline Middle school & 106 & 486 & 1.1 & $0.8-1.5$ & 0.56 \\
\hline High school & 203 & 979 & 1.0 & $0.8-1.3$ & 0.84 \\
\hline Undergraduate & 293 & 1463 & 1.0 & $0.8-1.2$ & 0.98 \\
\hline Graduate & 135 & 672 & 1.0 & & - \\
\hline \multicolumn{6}{|l|}{ Mother's education status } \\
\hline Neither reads nor writes & 133 & 538 & 0.9 & $0.6-1.4$ & 0.8 \\
\hline Reads and writes & 135 & 510 & 1.0 & $0.7-1.5$ & 0.9 \\
\hline Elementary school & 115 & 569 & 0.8 & $0.5-1.1$ & 0.2 \\
\hline Middle school & 103 & 525 & 0.7 & $0.5-1.1$ & 0.16 \\
\hline High school & 199 & 1030 & 0.7 & $0.5-1.1$ & 0.11 \\
\hline Undergraduate & 225 & 1107 & 0.8 & $0.5-1.1$ & 0.18 \\
\hline Graduate & 40 & 149 & 1.0 & & - \\
\hline \multicolumn{6}{|l|}{ Father smokes } \\
\hline Yes & 304 & 904 & 1.8 & $1.6-2.2$ & $<0.001$ \\
\hline No & 643 & 3529 & & & \\
\hline \multicolumn{6}{|l|}{ Mother smokes } \\
\hline Yes & 45 & 78 & 2.8 & $1.9-4.1$ & $<0.01$ \\
\hline No & 897 & 4308 & & & \\
\hline \multicolumn{6}{|l|}{ Brother smokes } \\
\hline Yes & 408 & 1986 & 0.9 & $0.8-1.04$ & 0.17 \\
\hline No & 578 & 2544 & & & \\
\hline \multicolumn{6}{|l|}{ Sister smokes } \\
\hline Yes & 383 & 425 & 6.1 & $5.2-7.2$ & $<0.01$ \\
\hline No & 602 & 4106 & & & \\
\hline \multicolumn{6}{|l|}{ Friends smoke } \\
\hline None & 86 & 2752 & 1.0 & & - \\
\hline Some & 259 & 1301 & 8.8 & $6.8-11.4$ & $<0.001$ \\
\hline Most & 407 & 296 & 44.0 & $33.6-57.7$ & $<0.001$ \\
\hline All & 85 & 36 & 75.5 & 473.0120 .9 & $<0.001$ \\
\hline
\end{tabular}

$O R=$ odds ratio $; C I=$ confidence interval. smoking status, brother's smoking status and year of study) which have been shown to be effect modifiers (statistically significant $P$-values) when stratified and when tested by Breslow-Day test as shown in Table 5 .

\section{Independent risk factors of smoking (multivariate analysis)}

Table 6 shows the results of stepwise logistic regression including statistically significant variables from the bivariate analyses. The most important independent predictors of smoking among the students in our sample were: friends' smoking status $(\mathrm{OR}=6.7$ for some, 31.7 for most and 54.9 for all friends, $P<0.001)$; sister's smoking $(\mathrm{OR}=2.2$, $P<0.001$ ); mother's smoking (OR $=2.1, P<0.006)$; marital status (OR $=1.7$ for single $P=0.014$ ) and older age $(\mathrm{OR}=1.2 ; P<0.001)$.

\section{Discussion}

The overall prevalence of smoking among students of different colleges/ sexes in our sample was estimated at $14.5 \%$. A recent systematic review of 66 studies reflecting an international comparison of tobacco smoking surveys conducted among medical students between 1976-2006 indicated that the overall prevalence ranged from $3 \%$ (in Australia) to 44\% (in Spain) [20]. Moreover, a recent compendium of tobacco consumption surveys in Saudi Arabia during the past decade (19992009) has shown that the prevalence of tobacco use among young adults of university age ranged from $2.4 \%-37.0 \%$ [18]. Recent estimates of tobacco consumption among male medical students in Riyadh, Saudi Arabia reflected a decline from 33\% in 1992 [21] to $13 \%$ in 2006 [22]. This seems to agree with our estimate of $14.5 \%$ and that of a survey carried out at University of Sharjah, United Arab Emirates, during 2005, which estimated the overall prevalence of smoking among its students at $15.1 \%$ 


\begin{tabular}{|c|c|c|c|c|c|c|}
\hline \multirow[t]{2}{*}{ Student variable/peer pressure } & \multicolumn{2}{|c|}{ Smoking status } & \multirow[t]{2}{*}{ OR } & \multirow[t]{2}{*}{$95 \% \mathrm{Cl}$} & \multirow{2}{*}{$\begin{array}{l}P \text {-value (chi } \\
\text { squared test) }\end{array}$} & \multirow{2}{*}{$\begin{array}{c}P \text {-value (Breslow- } \\
\text { Day test) }\end{array}$} \\
\hline & Yes & No & & & & \\
\hline \multicolumn{7}{|l|}{ Male } \\
\hline Some/most/all friends smoke & 713 & 1209 & 6.6 & 4.4-9.9 & $<0.001$ & 0.009 \\
\hline No friends smoke & 29 & 325 & 1.0 & & & \\
\hline \multicolumn{7}{|l|}{ Female } \\
\hline Some/most/all friends smoke & 118 & 414 & 12.7 & $8.9-18.1$ & $<0.001$ & \\
\hline No friends smoke & 54 & 2407 & 1.0 & & & \\
\hline \multicolumn{7}{|l|}{ Father smokes: yes } \\
\hline Some/most/all friends smoke & 276 & 350 & 29.2 & $16.4-53.1$ & $<0.001$ & 0.02 \\
\hline No friends smoke & 14 & 519 & 1.0 & & & \\
\hline \multicolumn{7}{|l|}{ Father smokes: no } \\
\hline Some/most/all & 545 & 1246 & 14.2 & 10.9-18.7 & $<0.001$ & \\
\hline No friends smoke & 67 & 2181 & 1.0 & & & \\
\hline \multicolumn{7}{|l|}{ Brother smokes: yes } \\
\hline Some/most/all friends smoke & 342 & 937 & 7.9 & $5.7-11.2$ & $<0.001$ & \\
\hline None & 45 & 983 & 1.0 & & & $<0.001$ \\
\hline \multicolumn{7}{|l|}{ Brother smokes: no } \\
\hline Some/most/all friends smoke & 509 & 695 & 31.6 & $22.4-44.6$ & $<0.001$ & \\
\hline No friends smoke & 41 & 1768 & 1.0 & & & \\
\hline \multicolumn{7}{|l|}{ Year of study: 1st to 4th year } \\
\hline Some/most/all & 595 & 1307 & 13.9 & $10.8-17.0$ & $<0.001$ & 0.002 \\
\hline No friends smoke & 77 & 2351 & 1.0 & & & \\
\hline \multicolumn{7}{|l|}{ Year of study: 5th and 6th year } \\
\hline Some/most/all friends smoke & 180 & 200 & 97.6 & $23.5-208.8$ & $<0.001$ & \\
\hline No friends smoke & 2 & 217 & 1.0 & & & \\
\hline
\end{tabular}

$O R=$ odds ratio $; C l=$ confidence interval.

[17]. Nevertheless, such estimates are still high among young educated adults who should be role models for their community, fighting tobacco use rather than using it.

Although bivariate analysis showed that sex was significantly associated with smoking status among students in our survey, further analysis showed that, in fact, sex was an effect modifier, related to peer pressure and smoking status. Such an observation differs from recent articles which dealt with sex as an independent fisk factore for smoking, such as a recent international comparison of smoking surveys among medical students [20], among Sharjah university students [17], as well as among adult Saudi nationals [23]. However, the prevalence of smoking among female students may be an underestimate, as smoking is considered taboo in conservative communities such as Saudi Arabia.

Considering students of Islamic studies as baseline (assuming them to be more conservative owing to the nature of their studies), students in health and non-health related subjects were at higher estimated risk of smoking. Such a finding agrees with those reported from the student survey at University of Sharjah where smokers were predominantly (89\%) from non-health related majors [17], and a recent study in Rawalpindi, Pakistan where smoking prevalence was estimated to be $32.7 \%$ among medical students compared with $41.0 \%$ among non medical students [24]. This reflects the possible effect of Islamic studies and healthrelated curricula on raising awareness of students, protecting them to a certain extent from taking up the habit of smoking.

In addition, we observed a highly statistically significant rising trend of smoking risk from 1st year students to 6th year students. A similar finding was reported from a recent Turkish longitudinal study of tobacco consumption among medical students in which about one-third of original non-smokers in the 1st year had become smokers by the end of the 6th year of study [25]. An Indian study reported a steady increase in smoking prevalence from $17 \%$ during the 1 st year to $43 \%$ in the 5 th year [26]. At a time when we expect that more university education prevents students 


\begin{tabular}{|c|c|c|c|}
\hline \multicolumn{4}{|c|}{$\begin{array}{l}\text { Table } 6 \text { Results of multiple logistic regression analysis of the sample of King Saud } \\
\text { University students, } 2009\end{array}$} \\
\hline Risk factor & Adjusted OR & $95 \% \mathrm{Cl}$ & $P$-value \\
\hline Age (years) & 1.2 & $1.1-1.2$ & $<0.001$ \\
\hline Marital status: single & 1.7 & $1.1-2.5$ & 0.014 \\
\hline Mother smokes: yes & 2.1 & $1.2-3.5$ & 0.006 \\
\hline Sister smokes: yes & 2.2 & $1.8-2.8$ & $<0.001$ \\
\hline \multicolumn{4}{|l|}{ Friends smoke } \\
\hline All & 54.9 & $32.5-92.5$ & $<0.001$ \\
\hline Most & 31.7 & $23.5-42.8$ & $<0.001$ \\
\hline Some & 6.7 & 5.1-8.8 & $<0.001$ \\
\hline
\end{tabular}

$O R=$ odds ratio $; C l=$ confidence interval.

from becoming smokers, it seems that stress and perceived relaxation and better mood, as usually reported by smokers, may be related to the observed increase in smoking prevalence during the final years of basic university education at King Saud University.

Father's, mother's and sister's smoking habits had a statistically significant effect on the smoking habits of their offspring/siblings. Such findings confirm similar results reported from the UAE indicating that having a smoking family member (father/mother/both) was an important predictor of smoking among University of Sharjah students [17]. In Bahrain too there were reports that the smoking status of fathers and brothers were significantly different between smokers and non-smokers [3]. In India a study found tobacco use was more common among male medical students belonging to families where tobacco use was prevalent [27].

The strongest predictor of smoking among students in our study was peer pressure (having a smoking friend), with regression analysis showing a rising trend from $\mathrm{OR}=6.7$ for some friends smoking to 54.9 for all friends as smokers. Such a finding has been consistently reported from numerous studies carried out in different Gulf nations, such as Saudi Arabia [4-6,22,23], UAE [17], Bahrain $[3,16]$ and outside the Gulf, such as from India [27], Pakistan [24] and Turkey [25]. However, it should be noted that sex, father's smoking, brother's smoking and year of study were shown to be effect modifiers (i.e. association of peer pressure with the smoking status of students in our sample).

Qualitative methods could be used to further study the findings of this quantitative study, to give more in depth understanding of this social phenomenon among university students. Moreover, better estimates of smoking among young women should be sought in further research among this sub-group of the community.

University students in Gulf Cooperation Council nations, as in Saudi Arabia, are vulnerable to taking up the habit of smoking, especially waterpipe and cigarettes among males. The importance of role-models (parents, siblings, peers, teachers, etc.) cannot be emphasized enough. Anti-smoking campaigns are warranted during university education to follow similar activities during basic education. Banning smoking on university premises can also help restrict students from smoking, as much as possible, in addition to providing on-campus special services which could assist smokers efficiently quit this addictive habit. Finally, sporting and exercise facilities should be availed to allow for dissipating energy of youngsters in this critical age.

\section{References}

1. Warren $\mathrm{CW}$ et al. Global tobacco surveillance system. The GTSS atlas. Atlanta, Georgia, Centers for Disease Control and Prevention, 2009.

2. Global youth tobacco survey (GYTS). Country factsheet of the Kingdom of Saudi Arabia 2007. Cairo, World Health Organization Regional Office for the Eastern Mediterranean, 2008.

3. Al-Haddad N, Hamadeh RR. Smoking among secondary school boys in Bahrain: prevalence and risk factors. Eastern Mediterranean Health Journal, 2003, 9:91-94.

4. Felimban FM. Jarallah JS. Smoking habits of secondary school boys in Riyadh, Saudi Arabia. Saudi Medical Journal, 1994, 15:438-492.

5. Jarallah JS et al. Predictors of smoking among male junior secondary school students in Riyadh, Saudi Arabia. Tobacco Control, 1996, 5:26-29.

6. Al-Faris EA. Smoking habits of secondary school boys in rural Riyadh. Public Health, 1995, 109:47-55. 7.

7. Al-Yousef MA, Karim A. Prevalence of smoking among high school students. Saudi Medical Journal, 2001, 22:872-874.
8. Moody PM. Factors associated with the initiation of smoking by Kuwaiti males. Journal of Substance Abuse, 1998, 10:375-384.

9. Bawazeer AA, Hattab AS, Morales E. First cigarette smoking experience among secondary-school students in Aden, Republic of Yemen. Eastern Mediterranean Health Journal, 1999, 5:440-449.

10. Maziak W, Mzayek F. Characterization of the smoking habit among high school students in Syria. European Journal of Epidemiology, 2000, 16:1169-1176.

11. Gadalla $\mathrm{S}$ et al. Prevalence of smoking among rural secondary school students in Qualyobia governorate. Journal of the Egyptian Society of Parasitology, 2003, 33 (Suppl):1031-1050.

12. Mandil A et al. Knowledge, attitudes and smoking pattern among nursing and laboratory technology students, Dammam, Saudi Arabia. Journal of Family and Community Medicine, 1999, 6(2):51-58.

13. Haddad LG, Malak MZ. Smoking habits and attitudes towards smoking among university students in Jordan. International Journal of Nursing Studies, 2002, 39:793-802. 
14. Nassar H. The economics of tobacco in Egypt. A new analysis of demand. Health, nutrition and population discussion paper. Washington DC, International Bank for Reconstruction and Development/World Bank, 2003.

15. Tamim $\mathrm{H}$ et al. Tobacco use by university students, Lebanon, 2001. Public Health, 2003, 98:933-939.

16. Hamadeh RR. Smoking habits of medical students in Bahrain Journal of Smoking-Related Diseases, 1994, 5:189-195.

17. Mandil A et al. Characteristics and risk factors of tobacco consumption among University of Sharjah students, 2005. Eastern Mediterranean Health Journal, 2007, 13:1449-1458.

18. Bassiony MM. Smoking in Saudi Arabia. Saudi Medical Journal, 2009, 30:876-881.

19. Smoking and tobacco use. GYTS core questionnaire. Centers for Disease Control and Prevention [online factsheet] (http:// www.cdc.gov/tobacco/global/gyts/questionnaire.htm, accessed 13 March 2011)

20. Smith DR, Leggat PA. An international review of tobacco smoking among medical students. Journal of Postgraduate Medicine, 2007, 53:55-62.
21. Jarallah JS. Smoking habits of medical students at King Saud University, Riyadh. Saudi Medical Journal, 1992, 13:510-513.

22. Al-Turki YA. Smoking habits among medical students in Central Saudi Arabia. Saudi Medical Journal, 2006, 27:700-703.

23. Saeed AA, Khoja T, Khan SB. Smoking behavior and attitudes among adult Saudi nationals in Riyadh City, Saudi Arabia. Tobacco Control, 1996, 5:215-219.

24. Mumtaz B et al. Comparison of smoking behaviour among medical and other college students in Rawalpindi. Journal of the College of Physicians and Surgeons--Pakistan, 2009, 19:7-10.

25. Senol $Y$ et al. The incidence of smoking and risk factors for smoking initiation in medical faculty students: cohort study. BMC Public Health, 2006, 6:128.

26. Singh SK et al. Smoking habits of the medical students. Indian Journal of Chest Diseases \& Allied Sciences, 1989, 31:99-103.

27. Kumari R, Nath B. Study on the use of tobacco among male medical students in Lucknow, India. Indian Journal of Community Medicine, 2008, 33:100-103.

\section{World No Tobacco Day}

On 31 st May each year WHO celebrates World No Tobacco Day, highlighting the health risks associated with tobacco use and advocating for effective policies to reduce consumption. Tobacco use is the second cause of death globally (after hypertension) and is currently responsible for killing one in 10 adults worldwide.

The World Health Assembly created World No Tobacco Day in 1987 to draw global attention to the tobacco epidemic and its lethal effects. It provides an opportunity to highlight specific tobacco control messages and to promote adherence to the WHO Framework Convention on Tobacco Control. Tobacco use is the number one preventable epidemic that the health community faces. 